\title{
AGEING IN SERBIA: PERCEPTIONS AND EXPERIENCES OF NURSING HOME RESIDENTS ${ }^{3}$
}

\begin{abstract}
Population ageing in Serbia has pervading effect on many societal spheres. Paradigm of active ageing highlights the importance for older to lead healthy and productive life. The aim of this paper is to explore active ageing practices of institutionalised older citizens considering their sociodemographic characteristics and migration background. Semi-structured interview, as a qualitative research method was used to grasp perceptions and experiences of 27 older residents in nursing homes regarding adjustment in later life and daily activities. Additional valuable insight on topic was gained from institutional social workers. According to the results, the routine of daily living of the elders varies depending on individual abilities, preferences, health, marital status and migration history. The findings suggest that institutional setting does not have to represent barrier to active ageing, with implications for further research and practice.
\end{abstract}

Keywords: active ageing, nursing homes, retirement return migration, Belgrade

\section{Introduction}

Fundamental changes in human behaviour characterised by low fertility and rising life expectancy are shaping demography of many European countries leading to population ageing, but not all societies are equally susceptible to those effects. Countries of western Balkans are seen as those with negative impact of demographic changes on health, pension and social protection systems, rising question whether desired and needed reforms would be timely implemented (Hoff, 2011; Botev, 2012). The personal characteristics of the elders determine their resources and preparedness for old age, while rapid population ageing is posing different structural problems such as decompression of kin availability and consequently to changes in institutional arrangements of elderly care (Ruspini, 2009; Van Malderen et al. 2013; Palloni, Pinto, Wong, 2009). Lack of longitudinal studies regarding population ageing in Serbia is limiting factor in the study of this

\footnotetext{
${ }^{1}$ lukicbodirogav@gmail.com

2 j.gnjatovic@gef.bg.ac.rs

3 This article is result of projects 47006 and 47007 of the Ministry of education, science and technological development of the Republic of Serbia.
} 
important topic, something to be expected since there is no symmetry in ageing research between European North and South, or East and West, which is additionally burdened by language barrier (Wahl, Deeg, Litwin, 2013).

The most important policy guidelines related to health, productivity and independency of the older population are glued together into paradigm of the active ageing (WHO, 2002) seen as potential remedy for population ageing (Walker, 2015). Definition of this paradigm goes from multidimensional, such as in holistic approaches (covering several policy fields), than unidimensional with emphasize to the specific activity of elders, to those with behavioral component being highlighted (Hamblin, 2013; Ervik, 2006; Boudiny, 2013). World Health Organisation (WHO, 2002) was pioneer in designing active ageing policy, emphasizing three pillars: participation, health and security of older people. The core of active ageing policy is in "activating certain forward looking social policies that can yield high economic and social returns" (Zaidi et al. 2013). Incorporating life course perspective and giving more attention to various groups of older citizens such as those institutionalized into active ageing research and concept framing has been especially stressed (Walker, 2002; Boudiny \& Mortelmans, 2011).

Serbia belongs to the so-called Mediterranean type of countries in which young people leave the parental home late and remain financially dependent on their parents, keeping strong emotional ties. The high unemployment rate in Serbia and in particular for young, hinders their independence (Tomanović et al. 2012). Another feature of societal traditionality is reflected in the fact that stigma related to living in a nursing home is still very strong (Milosavljević \& Antonijević, 2015). The capacity of public-owned nursing homes in Serbia is insufficient and with uneven geographical distribution, while the procedure of admission to the nursing home is regulated according to the Law on Social Protection. Similar to nursing homes in other countries (Fernandez-Mayoralas et al. 2015) the housing services consist of individual and shared rooms, meals and housekeeping. In nursing homes in Serbia users have not only residential, but also health and social services, cultural and recreational activities provided, all of which contribute to the quality of life of older people. According to 2014 data, more than a half of nursing home users in Serbia were women and widowed, about one third of users were independent (vital) users, and the majority of the nursing homes residents have no formal education or have only finished elementary school (Institute of Social Protection, 2015).

Additionally, Serbia is very old country, but population ageing is not in its full extent in present days since generational shift of numerous baby boomers born right after the WW2 (1947-1956) will contribute to deepening of this process. Expansion of emigration called "temporary employment abroad" (Bernard, 2012) in the 1960s is nowadays enabling aged migrants to acquire pension rights in countries where they worked, giving them opportunity to decide where to spend old age, so that about 10 per cent of beneficiaries in nursing homes in Serbia are retirement returnees from abroad (Milosavljević \& Antonijević, 2015). It is anticipated that these changes will pose huge burden on pension and health systems (Kupiszewski, Kupiszewska, Nikitović 2012; Stojilković 2010; Stojilković Gnjatović \& Sekulic 2017), rising many question for possible and viable policy options. It is no wonder that active ageing in a topic that gains more attention, but the question of continued activity of nursing home residents has been almost neglected (Van Malderen et al. 2013). This study is the first domestic attempt to tackle this issue, relying on numerous determinants and 
three pillars of WHO (2002) active ageing concept in order to contribute to the knowledge on perceptions and experiences of the older nursing home residents. The aim is to explore participation of elderly through their later life activity engagement, to investigate their feeling of security as proxy for family and social support and to assess the importance of institutional and societal environment for healthy ageing.

\section{Methods}

A qualitative approach was used in order to explore the active ageing concept in the institutional setting in Serbia, while providing the insights into the active ageing practices in nursing homes in different countries (Van Malderen et al. 2013; Fernandez-Mayoralas et al. 2015). Semi-structured interview was chosen, given the possibility to present respondents' own perceptions, opinions and feelings regarding researched issues while enabling clarification of answers and keeping validity and variability in the sample group of varied personal histories (Barriball \& While 1994). Authors directed the interview and firstly collected socio-demographic data, continuing with questions on other determinants of active ageing (perceptions and experiences of the nursing home residents on adjustment in later life and their activities) but allowed participants to raise other issues as well. The factors as health and social services, personal, behaviour, physical, social and economic determinants of active ageing (WHO, 2002) were grouped in three research topics: (a) later life activity and old age challenges as prerequisites/obstacles for participation; (b) social/family and support networks as security determinants and (c) the favourability of institutional and societal environment for health enhancement of older people living in nursing homes in Serbia.

The research was conducted in 2015 and 2016 in two largest ("Bežanijska kosa" and "Voždovac") out of four open - type nursing homes that are part of the Gerontological Centre of Belgrade. Social workers employed in nursing homes helped in recruitment of vital participants as they spread information about the research, its aims and topic as well as time and place of research. They indicated that the research was voluntary and how the information will be used. The participants who gave their consent have been recorded. Most interviews were conducted in a common living room of the nursing homes between breakfast and lunchtime as the social workers considered that time as the most appropriate. Nevertheless, very small number of the participants were interviewed in their rooms due to their own will. The interviews were led by one of two researchers and they lasted around 20-30 minutes. Total of 27 vital (according to physical and mental health) nursing home residents were interviewed until the saturation occurred and we have reached the point of no new themes and data (Fusch \& Ness, 2015). The recorded material was transcribed, ID numbers were added in the material, and content analysis and thematic analysis as described by Taylor-Powel and Renner (2003) were utilized to analyze the data, where key themes were marked prior the conclusion drawing. In order to further highlight the multidimensional dynamic process of active ageing within nursing homes additional interviews (on the topic of daily activities, routines and preferences of elderly nursing home residents) were carried out with two social workers employed in these institutions. 


\section{Results}

The research included 27 participants, aged 65 and older. Majority of participants were widowed. The number of participants with tertiary and secondary education were equal, while smaller number of participants had primary or incomplete primary education Table 1.

All participants have lived in the nursing home from one to five years. Out of nine participants with international migration history six were retirement return pensioners from France, Sweden and Germany while two participants were long term settled refugees that fled from Croatia in the 1990s. One participant was a marriage based immigrant from the former SSSR, living in Serbia for a very long time. Return retirement pensioners involved in our research have lived in countries of work for about 30 years. Their reasons for return vary and include personal, cultural and economic factors.

The thematic analysis is divided into three parts according to the distinct topics that the discussions were centred on: later life activity engagement and challenges faced in old age; social and support networks and the perception of institutional and societal environment in Serbia.

Later life activity engagement and challenges faced in old age

While psycho-physical activity is a prerequisite for good quality of life in the old age (Walker, 2005) the active ageing concept in nursing homes can optimise resident's quality of life (Van Malderen et al. 2013, 2016; Fernandez-Mayoralas et al. 2015). According to respondent's activity patterns they are engaged in physical, cultural, passive and social leisure activities (Fernandez-Mayoralas et al. 2015) organized through the nursing home (different commissions or sections) or are engaged with certain individual activity. Routines of daily living of researched participants include reading, solving crossword puzzles, watching TV, cultural activities (concerts, theatre, museums etc.), walking, creative activities, choir, exercises, trips, literary section, collecting leaves, watching movies, playing chess, planting flowers, helping other people etc.

The respondents stated their opinion on importance of some activities for health and preventing isolation but also regret for not having the opportunity to participate in certain activities for various reasons, including financial barriers for those activities that have to be paid extra.

"Walking is very important to me. I go often to the pool in the city also..." (5BR-M) "I'd participated in the choir but I'm tone-deaf" (2BR-F) "I have participated until I could, now I only watch the show" (7VL-F) "Rarely I go on picnics because of the finances" (4VL-M).

Some of the participants are trying to be involved in activities in the old age for which they consider to be missed out earlier in life. "I go when there are events and visits of residents from other nursing homes because -there- in Germany we did not go out anywhere... we did not have time ... we worked too much" (13RB-F). The relational status of the respondents affect activity patterns also. The only married respondent who lives with spouse in the nursing home said she accommodates the activities in line with his needs and obligations.

Management at nursing home "Bežanijska kosa" gave the possibility to the interested residents to use separate rooms in which certain crafts and other activities could be per- 
formed. The work makes them feel useful and contributes to preservation of their vitality and identity (Van't Leven \& Jonsson, 2002; Vasara, 2015). "I have a workshop here so I can help others in the home, reupholster furniture, cut the board... no one else is of my profession but there are also tailors here ... " (7BL-M).

Despite the fact that there are professional cooks and maids in the nursing home, it seems that women have the need to be engaged on these tasks in the apartments, which can be considered a habit from their own households, confirming other findings on gender differences in transition to retirement life (Bolzman \& Kaeser, 2012). Some female respondents even feel the need to further engage in the nursing home. "I love to take care of other tenants during the meal and to help them because I'm still relatively young ... regardless of the maids I take care of common room" (3BL-F).

Besides participation in activities that need extra payment, economic determinant reflects on the living conditions in the nursing home. The majority of respondents do not prefer to share the living and sleeping space. "I have my own habits" (1BL-M). However, only wealthier retirees can afford privacy in apartments while some respondents can not even afford a single room. Due to small number of apartments ${ }^{4}$, it often happens that residents are on long waiting list for this type of preferred accommodation.

"We have our key, we come and go as we want, like in a flat" (6BL-F).

Those who like to read highlighted the problem of a limited number of books in library in the nursing home, which is why some of the users go to other city libraries. When going out of the nursing home they mainly use public transportation, some have the help of relatives while taxi is rarely used. One respondent even has a car.

Common challenges faced by elderly respondents include economic hardship, health problems, regret for the loss, loneliness, and lack of privacy. When talking on aging and coping one participant say: "It goes all its course over the years...the old age like the old age I cannot be younger and healthier" (3VL-F).

\section{Social and support networks}

Support of family and friends is very important for the quality of life in the old age and healthy ageing. The majority of the research participants are widowed or divorced and most of them have children. There is a relatively strong frequency of friends and family members and visits, telephone contacts, contacts through Skype or smartphone. Some residents even go to visit or spend weekends with family. "My son has been coming to see me every day for the last 12 years" (8BL-M); "I go to visit my family once a month, even though they live in another city" (4BR-F). Geographical distance affects social support. When asked how she sees her role in the family, a female returnee from Sweden responded: "peripheral - due to physical distance".."but I don't feel lonely, I am very engaged here" (5BR-F)

Emotional support is the most common form of support, while respondents to a lesser extent get financial help from relatives, assistance related to transportation or other. In contrast to expected, older respondents frequently financially help younger family members, especially do returnees, and it gives them feeling of usefulness. "We all know

${ }^{4}$ The researchers had the opportunity to visit apartments that are equiped with own furniture and filled with personal things and memories of participants so they "feel like home". 
that today's young people live very difficult and that unemployment is high" (2VL-F); "I am glad I can help younger grandchild financially since he lost his job as redundant" (5VL-M).

When it comes to socializing with other residents, the respondents pointed that they are seeking for persons similar to them but also experiencing disappointments in social contacts. Even new love can be born. A good opportunity for socializing residents have in common spaces and through organised activities but they also use different ways to communicate with friends outside of nursing homes. Through organised activities and visits some of them made friendships with older from other nursing homes. "I immediately found a company" (3BL-F); "I am for hanging out but people are little drawn so I'm getting in the gear" (6VL-M) "I socialize via smart phone and Skype with my friends" (2BR-F) "In our room we get along great. We do not need social worker. We solve every issue together" (10BL-M).

Institutional and societal environment in Serbia

Our research results show that most of the respondents moved voluntarily to nursing home due to life events and age related changes (retirement, widowhood) or ininappropriate size/costs of the dwelling. Therefore, they do not have a sense of loss of control and autonomy (Vasara, 2015). "Before I arrived, I cleared out what was good for me and what not" (3VL-F)

Some of them felt unsecure and lonely at home. "Somehow you are protected here ..when you do not want to be alone you are not alone because you can always find a company" (9VL-M).

Regarding the experiences of institutional living in Serbia, supply of services and leisure activities are valued. "I was surprised by cleanness here and discipline"; "We do not have to cook, wash dishes, we have doctors". "I do not have to run to the clinic to schedule and wait at the pharmacy, here prescription is filled - also we have a specialist" (12VL-F). Female who resides in an apartment with her husband emphasizes the fact that her husband is ill and his need for medicine care as a reason for coming to the nursing home."Everything is available here... when you call an ambulance from the residential building it take them hours to come" (9BR-F).

In one case, we identified opposite opinions of spouses in older couples regarding moving to the nursing home (Vasara, 2015) expressed partly because of the age difference between spouses. „My wife is 10 years younger than me and she does not even want to hear to come here. I go home on weekends and over the summer. Here is warm during the winter while my house is in the suburb and there is no central heating" (5BR-M).

According to respondents there is an open concept atmosphere in nursing home.

"We are all accepted here as it should be" (1VR-M).

"I am so grateful because our country receives us - old and worn-out -and yet I feel terribly sorry if I occupy a place to someone who has no money" (4BR-F).

Our study confirms the findings of other researchers on the reluctance of the older population from Serbia to go in nursing homes in the countries in which they acquired the right to pension (Milosavljević \& Antonijević, 2015). Language barrier pose limitations on accessing welfare rights and service but also social networks especially after the death of a spouse (Cook, 2010; Hardill et al. 2005). According to one returnee "After my husband's death I did not see myself getting very old in foreign country. I was afraid that I would forget the language and would not be able to ask for a glass of water" (2BR-F). 


\section{Social workers views}

The unique perspective of social workers employed in nursing homes, as a kind of experts with constant involvement and observation of users, provided further insight onto the issue of differences in life styles, activity and behaviour of nursing home residents in Serbia. They stressed that different organised activities for nursing home residents are integral part of their routine. However, social workers noted that previous occupation and person's life history can influence adaptation and participation. For example military personal easily followed home's rules, but actors had difficulties to adjust to discipline. The social workers also emphasized the difference in behaviour, activity and needs of older population as a result of migration experience and difference in the living standards through life span. Those who have financial capital (mostly returnees) are willing to invest in their apartments even if larger construction works are needed (e.g. roof repair in the apartment on the last floor). Some of them donated medical devices to the institutions where they live. Generally returnees have more numerous and larger demands addressed to management contrary to other elders living in the nursing homes. Another interesting observation referred to returnees who are more participative than other users and involved in different activities. They emphasized the difference in attitude and looks of female returnees as attractive and more active compared to local women so "the local man go crazy for them".

\section{Discussion}

Based on the experiences of the residents and social workers, this study analysed later life activity engagement and participation, family and social support and institutional and societal environment in the context of nursing homes of Gerontological Centre of Belgrade. The findings attempt to contribute to the knowledge on the issue of active ageing in nursing homes (Van Malderen et al. 2013, 2016; Fernandez-Mayoralas et al. 2015) using Serbia as case study for the first time (to our knowledge). The conclusion of this study indicate the significance of active ageing determinants in the nursing homes, confirming that participation, security and health are all very important pillars for active ageing policy (WHO, 2002; Van Malderen et al. 2013). However, due to the small sample size, general conclusions cannot be drawn based on this particular research. One should also have in mind different perspectives of nursing home residents speaking from personal experience and perspective of social workers as experts.

Important and integral dimension of active ageing is independence in the old age (WHO, 2002). The overall impression is that the respondents are very active and independent but chose to live in institution. Key findings from interviews suggest that habits have already been formed while the routine of daily living of the elders and their activity patterns varies depending on individual abilities, preferences, age, health and marital status. Finances also play an important role for participation in some activities. Most of the respondents are very participative on individual and organisational levels (Van Malderen et al. 2013) while our findings confirmed differences in activity patterns of females and males upon retirement (Bolzman \& Kaeser, 2012). Recognition of factors affecting activity patterns "help to draw attention to the need for compensatory mechanisms to support successful ageing” (Horgas, Wilms, Baltes 1998; 567). This is especially important in case 
of institutional living. According to our findings, statements related to later life activity engagement and challenges faced in the old age encompassed behavioural determinants related to healthy lifestyle, determinants related to personal and physical environment and economic determinants of the active ageing determinants identified by WHO (2002) while confirming the importance of participation to active ageing in residential care (Van Malderen et al. 2013).

The empirical results show also importance of the determinants related to the social environment (WHO, 2002; Van Malderen et al. 2013) for older living in the nursing homes. Social participation and integration benefits the quality of life of older (Walker 2005), although, according to respondents, social relations sometimes lead to disputes among them, which they solve themselves or with the help of social workers. Our results indicate that family and friends are source of different kind of support for nursing home residents. Some of our respondents even use modern information and communication technologies to communicate. It is used more by return pensioners compared to other interviewees, which can be attributed to their faster acceptance of innovations due to lifestyle and preferences influenced by migration history. Our results confirm findings of Van Malderen et al. (2013) that older can age actively in nursing homes where they are not necessarily isolated from community, but taking the best of both worlds. Though there are suggestions (Walters, 2000) that presence of spouse is largely incompatible with nursing home residence there were exceptions in our findings (married couple living in a nursing home, married man living in the nursing home during winter and visiting home occasionally).

Reflection on decision to live institutionally indicates that those who have independently made a decision to move to the nursing home are satisfied with life in an institution, care, environment and services and feel like they have control over their lives. The importance of the active ageing determinants related to health and social service system (WHO, 2002; Van Malderen et al. 2013) and certain advantages of living in a nursing home are highlighted, especially regarding variety of services and organised activities that are provided by nursing home. The fact that health system in Serbia is burdened by large number of elders as well as insufficient staff due to high emigration of health workers to Western European countries which affects the quality and availability of health services (Krstic \& Ljubicic, 2015) is well known to respondents who are aware of benefits that accommodation in the nursing home gives. We emphasised that familiar environment facilitates healthy ageing of migrants (Sadarangani \& Jun 2015) even if it is ageing in institution.

The research also sheds light on the still insufficiently explored link between migration and ageing in Serbia (Manojlović, 2002; Milosavljević \& Antonijević, 2015; Lukić, 2015) contributing to better understanding of the effects of migration experiences on activity patterns and quality of life of elders. Our findings also revealed how decision where to live affects pension value for return retirement pensioners based on differences in cost of living in Serbia and other countries. Compared to other participants, return retirement pensioners stand out in lifestyle and higher income that allows them better quality of spare time as well as accommodation confirming that as outlined by Ackers and Dwyer (2002:107) money matters. Since they have planned return (temporary migration strategy) they are supposed to be target savers and positively selected in terms of income 
(Rodriguez \& Egea, 2006). There are indications that return retirement pensioners can afford different lifestyle and accommodation compared to other groups of the elders. The majority of respondents have capacity to contribute to families and communities, while the finances are significant factor that enables better quality of life in old age. According to our respondents, there is an open culture (Van Malderen et al. 2013) in nursing home. Long term settled refugees from the former republics of Yugoslavia and the return pensioners enjoy the rights guaranteed by law including the accommodation in the nursing homes. The returnees, for whom determinants of active ageing related to social environment (WHO, 2002) seem to be very important, especially value this opportunity while there are findings that in other countries older returnees are facing difficulties to find place in nursing homes (Hardill et al. 2005).

\section{Conclusion}

Any framing of future population policy in Serbia has to consider the fact that demographic ageing is at present and will be in the future one of the most prominent challenge. Paradigm of active ageing is the most appealing for strategic purposes since it highlights the importance for older to lead healthy and productive life and to be more involved in community. Active ageing, therefore, gives important room for manoeuvring, confirming the need for permanent research of different possibilities and various reserves that older people have. Still, given that older people in Serbia are very heterogeneous group studying active ageing has to take into consideration numerious factors such as migration history, geographic distribution, residential preferences, economic outlooks etc. of elderly. Generating from our research, implications for policy concerning the elders in Serbia show that active ageing in nursing homes in Serbia can be realised with with more free programs and with help of return retirement pensioners as important agents of change.

Future research in (both state and private) nursing homes can further highlight the determinants of active ageing that could positively affect mitigation of unfavourable demographic trends. Also, in defining effective measures for the purpose of improvement of the quality of life of older citizens in Serbia, further efforts of professionals who provide services to older adults and policy makers are needed. Defining effective measures for the purpose of improvement of the quality of life of older citizens and pursuing the active ageing concept in nursing homes means respecting differences among heterogeneous groups of older people. 
Весна М. Лукић, Јелена Н. Стојилковић Гњатовић, Сйареюе у Србији: йериейције...

Весна М. Лукић ${ }^{1}$

Институт друштвених наука, Београд

Јелена Н. Стојилковић Гњатовић²

Универзитет у Београду, Географски факултет

Београд (Србија)

\title{
СТАРЕЊЕ У СРБИЈИ: ПЕРЦЕПЦИЈЕ И ИСКУСТВА ЛИЦА У ДОМОВИМА ЗА СТАРЕ
}

\author{
(Превоg In Extenso)
}

Сажетак: Старење становништва у Србији је процес са израженим утицајима на различите друштвене сфере. Парадигма активног старења наглашава колико је значајно да старији становници воде здрав и продуктиван живот. Циљ рада је да се истражи пракса активног старења институционализованих старијих лица, узимајући у обзир њихове социодемографске карактеристике и миграциону историју. Као квалитативна истраживачка метода коришћен је полуструктурирани интервју, како би се открила искуства и ставови 27 старијих испитаника смештених у старачким домовима по питању њихових дневних активности и прилагођавања на процес старења. Вредне увиде у тему дала су и запажања социјалних радника запослених у овим институцијама. Према резултатима истраживања, дневна рутина старијих зависи од њихових личних способности, здравственог и брачног статуса као и миграционе историје. Налази указују да институционални оквир не мора да представља кочницу за активно старење, што може бити од значаја за могуће правце даљих истраживања али и одговарајуће политике и мере.

Кључне речи: активно старење, домови за стара лица, повратне миграције пензионера, Београд

\section{Увод}

Темељне промене у људском понашању које карактерише ниска репродуктивност и растуће очекивано трајање живота обликују демографију многих европских земаља што доводи до старења становништва, мада нису сва друштва подједнако подложна тим ефектима. Земље западног Балкана сматрају се онима са негативним утицајем демографских промена на здравство, пензијски и систем социјалне заштите, постављајући питање да ли ће жељене и потребне реформе бити право-

${ }^{1}$ lukicbodirogav@gmail.com

2 j.gnjatovic@gef.bg.ac.rs

3 Овај чланак је резултат пројеката 47006 и 47007 Министарства просвете, науке и технолошког развоја Републике Србије. 
времено имплементиране (Hoff, 2011; Botev, 2012). Личне карактеристике старијих људи одређују њихове ресурсе и спремност за старост, док убрзано старење становништва доводи до различитих структуралних проблема као што је сужавање сродничке базе и, сходно томе, промена у институционалном збрињавању старих лица (Ruspini, 2009; Van Malderen et al. 2013; Palloni, Pinto, Wong, 2009). Недостатак лонгитудиналних студија о старењу становништва у Србији је ограничавајући фактор у проучавању ове важне теме, што је очекивано јер не постоји симетрија у истраживању старења између европског севера и југа, или истока и запада, који је додатно оптерећен језичком баријером (Wahl, Deeg, Litwin, 2013).

Најважније смернице у области политика здравља, продуктивности и независности старије популације спојене су у парадигму активног старења (WHO, 2002) која се сматра потенцијалним леком за старење становништва (Walker, 2015). Дефиниција ове парадигме креће од вишедимензионалних приступа, као што су холистички (који покривају неколико области политике), преко једнодимензионалних са нагласком на специфичну активност старијих, ка оним са истакнутом компонентом понашања (Hamblin, 2013; Ervik, 2006; Boudiny, 2013). Светска здравствена организација (WHO, 2002) била је пионир у креирању политике активног старења, наглашавајући три њена стуба: укљученост, здравље и сигурност старијих људи. Језгро политике активног старења је у „активирању одређених социјалних политика које гледају у будућност и које могу донети велику економску и друштвену корист“ (Zaidi et al. 2013). Посебно се наглашава инкорпорирање перспективе даљег животног тока и придавање веће пажње различитим групама старијих грађана, као што су они институционализовани, при истраживању активног старења и концептуалном обликовању (Walker, 2002; Boudiny, Mortelmans, 2011).

Србија припада такозваном медитеранском типу земаља у којима млади касније напуштају родитељски дом и остају финансијски зависни од својих родитеља, задржавајући снажне емоционалне везе са њима. Висока стопа незапослености у Србији, а посебно код младих, отежава њихову независност (Tomanović et al., 2012). Друга карактеристика друштвене традиције огледа се у чињеници да је стигма која се односи на живот у старачком дому и даље веома јака (Milosavljević, Antonijević, 2015). Капацитет државних домова за стара лица у Србији је недовољан и карактерише га неједнака географска расподела, док је поступак пријема у домове регулисан Законом о социјалној заштити. Слично као у домовима за стара лица у другим земљама (Fernandez-Mayoralas et al., 2015), услуге становања се састоје од појединачних и заједничких соба, оброка и одржавања. У домовима за стара лица у Србији корисницима су на располагању не само резиденцијалне, већ и здравствене и социјалне услуге, као и културне и рекреативне активности које доприносе квалитету живота корисника. Према подацима из 2014. године, више од половине корисника домова за старе у Србији чине жене и особе које су изгубиле супружника, око једну трећину чине независни (витални) корисници, а већина становника домова за стара лица нема формално образовање или има само завршену основну школу (Institute of Social Protection, 2015).

Додатно треба рећи да је Србија веома стара земља, али да старење становништва тренутно није изражено у пуном обиму јер ће генерацијска смена бројних „бејби бумера“ (енг. baby boomers) рођених одмах после Другог светског рата 
Весна М. Лукић, Јелена Н. Стојилковић Гњатовић, Сйареюе у Србији: йериейције...

(1947-1956) допринети продубљивању овог процеса. Јачање емиграције шездесетих година прошлог века под називом „привремено запошљавање у иностранству“ (Bernard, 2012) данас омогућава старијим мигрантима да стекну права на пензију у земљама у којима су радили, дајући им могућност да одлуче где да проведу старост, тако да око 10\% корисника домова за стара лица у Србији чине пензионисани повратници из иностранства (Milosavljević, Antonijević, 2015). Очекује се да ће ове промене представљати огроман терет за пензијски и здравствени систем (Kupiszewski, Kupiszewska, Nikitović 2012; Stojilković 2010; Stojilković Gnjatović, Sekulić, 2017), што доводи до многих питања у вези са могућим и одрживим политикама. Није ни чудо да је активно старење тема која заокупља све већу пажњу, док је питање континуираних активности становника домова за стара лица готово занемарено (Van Malderen et al., 2013). Ова студија је први домаћи покушај да се покрене ово питање ослањајући се на бројне детерминанте и три стуба концепта активног старења Светске здравствене организације (WHO, 2002) како би се допринело знању о перцепцији и искуству корисника домова за стара лица. Циљ је да се истражи укљученост старијих особа кроз њихово ангажовање у животним активностима у старијем животном добу, да се истражи њихов осећај сигурности у погледу породичне и друштвене подршке и да се процени значај институционалног и друштвеног окружења за здраво старење.

\section{Метод}

Коришћен је квалитативни приступ истраживању концепта активног старења у институционалном окружењу у Србији, уз истовремени увид у праксу активног старења у домовима за стара лица у различитим земљама (Van Malderen et al., 2013; Fernandez-Mayoralas et al., 2015). Изабран је полуструктурирани интервју, с обзиром на могућност представљања властитих перцепција, мишљења и осећања испитаника у вези са истраживаним питањима, уз могућност појашњења одговора и задржавање ваљаности и варијабилности на узорку групе са различитом личном историјом (Barriball, White, 1994). Аутори су водили интервју и најпре прикупили социо-демографске податке, настављајући са питањима о другим детерминантама активног старења (перцепције и искуства становника домова за стара лица о прилагођавању старијем животном добу и њиховим активностима), али су и испитаницима омогућили да покрену и друга питања. Фактори као што су здравствене и социјалне услуге, личне, понашајне, физичке, социјалне и економске детерминанте активног старења (WHO, 2002) груписани су у три истраживачке теме: (а) активност у старијем животном добу и изазови старости као предуслови/препреке за укљученості; (б) друштвене и породичне мреже подршке као детерминанте сиіурностии и (в) погодност институционалног и социјалног окружења за побољшање зgравља старијих особа које живе у домовима за старе у Србији.

Истраживање је спроведено 2015. и 2016. године у два највећа („Бежанијска коса“ и „Вождовац“) од четири дома за стара лица отвореног типа који раде у склопу Геронтолошког центра Београда. Социјални радници запослени у домовима помогли су у одабиру виталних испитаника тако што су ширили информације о истраживању, његовим циљевима и теми, као и времену и месту одржавања 
истраживања. Навели су да је истраживање добровољно и начин на који ће се информације користити. Евидентирани су учесници који су дали свој пристанак. Већина интервјуа обављена је у заједничкој дневној соби у домовима за стара лица у време између доручка и ручка, јер су социјални радници сматрали да је то време најприкладније. Ипак, један мали број испитаника је интервјуисан у њиховим собама, јер су изразили такву жељу. Интервјуе је водила једна од две истраживачице и трајали су око 20-30 минута. Укупно 27 виталних становника старачког дома (према физичком и менталном здрављу) интервјуисано је до засићења и тачке у којој није било нових тема и података (Fusch, Ness, 2015). Снимљени материјал је транскрибован, материјалу су додељени идентификациони бројеви, а подаци су анализирани у складу са анализом садржаја и тематском анализом Тејлор-Пауелове и Ренера (Taylor-Powel, Renner, 2003), где су кључне теме обележене пре доношења закључка. Како би се додатно нагласио вишедимензионални динамичан процес активног старења у домовима за стара лица, обављени су додатни интервјуи (на тему дневних активности, рутина и склоности старијих корисника) са два социјална радника запослена у тим институцијама.

\section{Резултати}

Истраживање је обухватило 27 испитаника, старијих од 65 година. Већина испитаника су особе које су изгубиле супружника. Број испитаника са терцијарним и средњим образовањем је био једнак, док је мањи број испитаника имао основно или непотпуно основно образовање Табела 1.

Сви испитаници су живели у дому за старе од једне до пет година. Од девет испитаника са историјом међународне миграције, било је шест пензионера који су се вратили из Француске, Шведске и Немачке, док су два испитаника била дугорочно настањена избегла лица избегла из Хрватске деведесетих година. Један од испитаника био је имигрант по брачној основи из бившег СССР-а, који је дуго живио у Србији. Пензионери повратници који су укључени у наше истраживање живели су у земљама где су радили око 30 година. Њихови разлози за повратак варирају и укључују личне, културне и економске факторе.

Тематска анализа је подељена на три дела у складу са различитим темама на које су дискусије биле фокусиране: укљученост у активности у старијем животном добу и изазови с којима се старе особе суочавају; друштвене и мреже подршке и перцепција институционалног и друштвеног окружења у Србији.

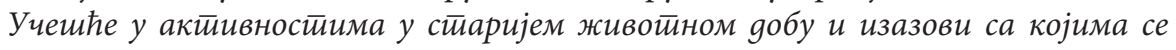

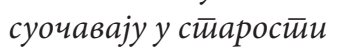

Како је психофизичка активност предуслов за добар квалитет живота у старости (Walker, 2005), концепт активног старења у домовима за стара лица може да оптимизује квалитет живота корисника (Van Malderen et al. 2013, 2016; FernandezMayoralas et al., 2015). Посматрајући обрасце активности испитаника, они се баве физичким, културним, пасивним и друштвеним слободним активностима (Fernandez-Mayoralas et al., 2015) које се организују преко домова за стара лица (различите комисије или секције) или се баве одређеним појединачним активностима. Свакодневне рутине испитаника укључују читање, решавање укрштеница, гледање 
Весна М. Лукић, Јелена Н. Стојилковић Гњатовић, Сйареюе у Србији: йериейције...

телевизије, културне активности (одлазак на концерт, у позориште, музеј, итд.), ходање, креативне активности, хор, вежбе, излете, књижевне секције, сакупљање лишћа, гледање филмова, играње шаха, садња цвећа, помагање другим људима итд.

Испитаници су изразили мишљење о важности неких активности за здравље и спречавање изолације, али и жаљење што нису имали прилику да учествују у одређеним активностима из различитих разлога, укључујући и финансијске баријере код оних активности које се додатно плаћају.

„Ходане ми је веома важно. Честио ияем до базена у іраgу...” (5BR-M) „Учестивовала бих у хору, али немам слуха.“ (2BR-F) „Учесиввовала сам док сам моіла, саgа само іледам настиуи. “(7VL-F) „Рейко ияем на излеиее збоі финансија.“ (4VL-M)

Неки од испитаника покушавају да се у старости укључе у активности које сматрају пропуштеним раније у животу. „Иgем каgа има gоїађаја и йосетиа корисника из gруіих домова за стиаре јер, йамо, у Немачкој, нисмо никуgа излазили... нисмо имали времена... ирревише смо раgили." (13RB-F) Брачни статус испитаника такође утиче на обрасце активности. Једина удата особа која живи са супружником у старачком дому каже да активности прилагођава његовим потребама и обавезама.

Управа старачког дома „Бежанијска коса“ је дала могућност заинтересованим станарима да користе одвојене просторије у којима могу да се обављају поједини занати и друге активности. Рад чини да се они осећају корисним и доприноси очувању виталности и идентитета корисника (Van't Leven, Jonsson, 2002; Vasara, 2015). „Овgе имам раяионииу йако gа моїу gа йомоїнем друіима у дому, ирресвучем намешйај, исечем йлочу ... нико gруіи није из моје йрофесије, али има и кројача..." (7BL-M)

Упркос чињеници да у домовима за стара лица има професионалних кувара и помоћног особља, чини се да жене у домовима имају потребу да се ангажују на тим задацима, што се може сматрати навиком коју носе из сопствених домаћинстава, потврђујући друге налазе о родним разликама када се ради о преласку на живот у пензији (Bolzman, Kaeser, 2012). Неке испитанице чак осећају потребу за даљим ангажманом у старачком дому. „Волим gа се бринем о gруіим сиианарима за време оброка и яа им йомоїнем јер сам још релайивно млаgа ... без обзира на йомоћно особле, бринем се о зајеgничком иростиору." (3BL-F)

Поред учешћа у активностима које се додатно плаћају, економска детерминанта одражава се на животне услове у дому за стара лица. Већина испитаника не преферира да дели дневни и спаваћи простор: „Имам своје навике.“ (1BL-M) Међутим, само имућнији пензионери могу да приуште приватност у апартманима, док неки испитаници не могу да приуште ни једнокреветну собу. Због малог броја апартма$\mathrm{Ha}^{4}$, често се дешава да су корисници на дугој листи чекања за ову врсту смештаја.

„Имамо кључ, gолазимо и о gлазимо како желимо, као у сииану." (6BL-F)

Они који воле да читају истакли су проблем ограниченог броја књига у библиотеци у домовима за стара лица, због чега неки корисници иду у друге градске библиотеке. Када излазе из дома углавном користе јавни превоз, неки имају помоћ рођака, док се такси ретко користи. Један испитаник има чак и аутомобил.

\footnotetext{
${ }^{4}$ Истраживачи су имали прилику да посете апартмане који су опремљени сопственим намештајем и испуњени личним стварима и сећањима корисника тако да се „осећају као код куће“.
} 
Заједнички изазови са којима се суочавају старији испитаници су економске тешкоће, здравствени проблеми, жал због губитка, усамљеност и недостатак приватности. Када се говори о старењу и суочавању, једна од испитаница каже: „Све

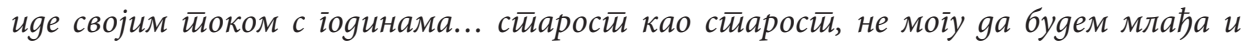
здравија." (3VL-F)

\section{Социјалне мреже и мреже подршке}

Подршка породице и пријатеља је веома важна за квалитет живота у старости и за здраво старење. Већина испитаника је изгубила супружника, или је разведена, и већина има децу. Релативно је велика учесталост посета пријатеља и чланова породице, телефонских контаката, контаката путем апликације Skype или паметног телефона. Неки корисници чак иду у посету или проводе викенде са породицом. „Син gолази gа ме вияи свакоі gана у йослеgних 12 іодина“ (8BL-M); „Иgем у йосейу својој йородици јеgном месечно, иако живе у gруїом їраgу." (4BR-F) Географска удаљеност утиче на друштвену подршку. На питање како види своју улогу у породици, повратница из Шведске одговорила је: „Периферно - збоі физичке уgаљеностии... али не осећам се усамлено, веома сам анілжована овgе." (5BR-F)

Емотивна подршка је најчешћи облик подршке, док испитаници у мањој мери од родбине добијају финансијску помоћ, помоћ везану за транспорт или друго. За разлику од очекиваног, старији испитаници често финансијски помажу млађе чланове породице, а нарочито то чине повратници из иностранства и то им даје осећај корисности. „Сви знамо gа gанашюи млаgи љуgи живе веома иеешко и gа је незайослености висока“ (2VL-F); "Драїо ми је шито моіу gа финансијски йомоїнем млађем унуку јер је изїубио йосао као иеехнолошки вишак." (5VL-M)

Када је у питању дружење са другим становницима, испитаници су истакли да траже особе сличне себи, али и да доживљавају разочарења у друштвеним контактима. Чак се може родити и нова љубав. Корисници имају прилику за дружење у заједничким просторијама и кроз организоване активности, али они користе и различите видове комуникације са пријатељима изван домова за стара лица. Неки од њих су се спријатељили са старијим особама из других домова кроз организоване активности и посете. „Оوмах сам нашла gрушишво (3BL-F); „Ја сам за gружене,

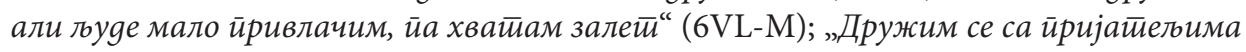
ирреко йаметиноі йелебона и Skyре-а“ (2BR-F); „У нашој соби се одлично слажемо. Не йреба нам соиијални раяник, већ сваки ирроблем решавамо зајеgно“ (10BL-M).

\section{Институционална и друштвена средина у Србији}

Резултати нашег истраживања показују да се већина испитаника добровољно преселила у дом за стара лица због животних околности и промена у вези са старошћу (одлазак у пензију, губитак супружника) или величине стана и високих трошкова становања. Према томе, они немају осећај губитка контроле и аутономије

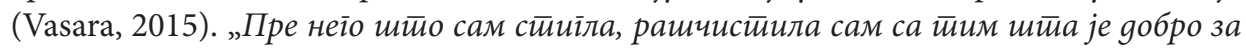
мене, а шииа не." (3VL-F)

Неки од њих су се осећали несигурно и усамљено код куће. „Некако си овgе

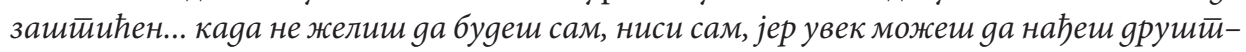
во." (9VL-M) 
Весна М. Лукић, Јелена Н. Стојилковић Гњатовић, Сйареюе у Србији: йериейције...

Што се тиче искуства живота у оквиру институције у Србији, вреднује се понуда услуга и активности у слободно време. „Била сам изненађена чистиоћом и guсиийлином“; „Не морамо gа кувамо, иеремо суgове, имамо докйоре“; „Не морам gа йрчим у болнииу gа закажем и чекам реg у айоиеци, овgе се добију лекови - йакође имамо сиеицјалисиие“ (12VL-F). Жена која живи у апартману са супругом као разлог доласка у дом за старе наглашава чињеницу да је њен муж болестан и да му је по-

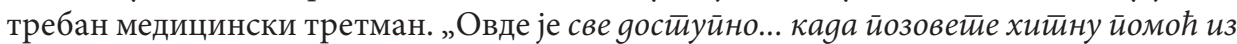
стиамбене зірраgе, йреба им времена gа gођу." (9BR-F)

У једном случају, идентификовали смо супротна мишљења супружника у вези с пресељењем у дом за стара лица (Vasara, 2015) која су делом резултат разлике у годинама између супружника. „Моја жена је 10 іоgина млађа оg мене и не жели ни gа чује gа gође овамо. Иуем кући викендом и иреко летиа. Овgе је йойло йоком зиме, док је моја кућа у йреgірађу и нема ценйрално ірејане." (5BR-M)

Према мишљењу испитаника, у домовима за стара лица постоји атмосфера отворености. „Сви смо овgе йрихваћени како тиреба.“ (1VR-M) „Веома сам захвална

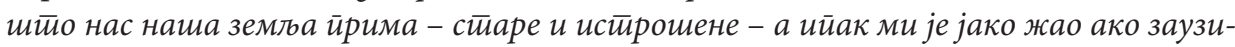
мам местио некоме ко нема нови,а." (4BR-F)

Наша студија потврђује налазе других истраживача о оклевању старије популације из Србије да живи у домовима за стара лица у земљама у којима су стекли право на пензију (Milosavljević, Antonijević, 2015). Језичка баријера поставља ограничења приступу социјалним правима и услугама, али и социјалним мрежама, нарочито након смрти супружника (Cook, 2010; Hardill et al., 2005). Према једној

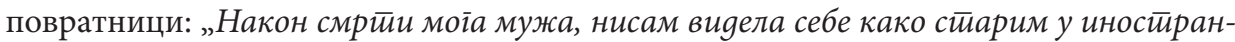
стиву. Плашила сам се gа ћу gа заборавим језик и gа нећу моћи gа йойражим чашу воge." (2BR-F)

\section{Перспектива социјалних радника}

Јединствена перспектива социјалних радника запослених у домовима за стара лица, као врсте стручњака са сталним ангажовањем и могућношћу посматрања корисника, пружила је даљи увид у питање разлика у животним стиловима, активностима и понашању становника домова за стара лица у Србији. Нагласили су да су различите организоване активности за становнике домова за стара лица саставни део њихове рутине. Међутим, социјални радници су приметили да претходно занимање и животна историја особе могу да утичу на адаптацију и укљученост. На пример, војна лица лако прате кућни ред, али глумци су имали потешкоћа да се прилагоде дисциплини. Социјални радници су такође нагласили разлике у понашању, активностима и потребама старијих људи које су резултат миграционог искуства и разлике у животном стандарду кроз животни век. Они који имају финансијски капитал (углавном повратници) спремни су да улажу у своје апартмане, чак и ако је потребно извести веће грађевинске радове (нпр. поправак крова у апартману на последњем спрату). Неки од њих донирали су медицинске уређаје институцијама у којима живе. Рекло би се да повратници руководству упућују бројније и веће захтеве у односу на друге станаре. Још једно занимљиво запажање односило се на повратнике који су више партиципативни од других корисника и који су укључени у различите активности. Они су нагласили разлику у ставовима и физичком изгледу 
жена повратница као атрактивнијих и активнијих у поређењу са локалним женама, па „локални мушкарци луде за њима“.

\section{Дискусија}

На основу искустава корисника и социјалних радника, ова студија је анализирала активност и укљученост у животне активности у каснијем животном добу, породичну и друштвену подршку и институционалну и друштвену средину у контексту домова за стара лица који припадају Геронтолошком центру Београда. Налази треба да допринесу знању о изазову активног старења у домовима за стара лица (Van Malderen et al., 2013, 2016; Fernandez-Mayoralas et al., 2015), користећи Србију као студију случаја по први пут (према нашим сазнањима). Закључак ове студије указује на значај детерминанти активног старења у домовима за стара лица, потврђујући да су укљученост, сигурност и здравље веома важни стубови политике активног старења (WHO, 2002; Van Malderen et al., 2013). Међутим, због мале величине узорка, није могуће извући опште закључке из овог истраживања. Треба имати у виду и разлике у перспективи становника домова за старе који говоре из личног искуства и перспективи социјалних радника као стручњака.

Важна и интегрална димензија активног старења је независност у старости (WHO, 2002). Општи утисак је да су испитаници веома активни и независни, али да су одлучили да живе у оквиру институције. Кључни налази интервјуа сугеришу да су навике већ формиране, док рутина свакодневног живота старих особа и њихове активности варирају у зависности од индивидуалних способности, склоности, старости, здравља и брачног статуса. Финансије такође играју важну улогу када се ради о учешћу у неким активностима. Већина испитаника је веома партиципативна на индивидуалном и организационом нивоу (Van Malderen et al., 2013), а наши налази су потврдили разлике у обрасцима активности након одласка у пензију код жена и мушкараца (Bolzman, Kaeser, 2012). Уочавање фактора који утичу на обрасце активности „помаже да се скрене пажња на потребу за компензацијским механизмима за подршку успешном старењу" (Horgas, Wilms, Baltes, 1998; 567). Ово је посебно важно у случају живота у оквиру институције. Према нашим налазима, изјаве корисника које се односе на ангажовање у животним активностима у каснијем животном добу и изазове са којима се суочавају у старости обухватају детерминанте у вези са здравим начином живота, са личном и физичком околином и економске детерминанте одредница активног старења које је утврдила С3О (WHO, 2002), потврђујући важност учешћа у активном старењу у домовима за стара лица (Van Malderen et al., 2013).

Емпиријски резултати показују и значај одредница у вези са друштвеним окружењем (WHO, 2002; Van Malderen et al., 2013) за старије особе које живе у домовима за стара лица. Социјална укљученост и интеграција доприносе квалитету живота старијих (Walker, 2005), иако, према испитаницима, друштвени односи понекад доводе до спорова међу њима које решавају сами или уз помоћ социјалних радника. Наши резултати указују на то да су породица и пријатељи извор различитих типова подршке становницима старачког дома. Неки од наших испитаника чак користе модерне информационе и комуникационе технологије за комуникацију. 
Весна М. Лукић, Јелена Н. Стојилковић Гњатовић, Сйареюе у Србији: йериейције...

Више их користе пензионери повратници у односу на друге испитанике, што се може приписати бржем прихватању иновација због начина живота и преференција услед миграционе историје. Наши резултати потврђују налазе Ван Малдерена и сарадника (Van Malderen et al., 2013) да старији грађани могу активно да старе у домовима у којима нису нужно изоловани од заједнице, већ узимају најбоље од оба света. Иако постоје сугестије (Walters, 2000) да је присуство супружника у великој мери неспојиво са животом у дому за стара лица, у нашим налазима било је изузетака (брачни пар који живи у старачком дому, ожењен човек који живи у дому за старе и повремено иде кући).

Разматрање одлука на живот у оквиру институције указује на то да су они који су самостално донели одлуку да се преселе у дом за стара лица задовољни животом у институцији, негом, окружењем и услугама и осећају да имају контролу над својим животима. Истакнута је важност детерминанти активног старења које се односе на систем здравствених и социјалних услуга (WHO, 2002; Van Malderen et al., 2013) и одређене предности живота у дому за старе, посебно у погледу разноликости услуга и организованих активности које пружа дом. Чињеница да је здравствени систем у Србији оптерећен великим бројем старих, као и недовољним бројем особља због велике емиграције здравствених радника у земље западне Европе, што утиче на квалитет и доступност здравствених услуга (Krstić, Ljubičić, 2015), добро је позната испитаницима који су свесни погодности које пружа смештај у дому за стара лица. Нагласили смо да познато окружење олакшава здраво старење миграната (Sadarangani, Jun, 2015), чак и ако се старење одвија у оквиру институције.

Истраживање такође осветљава још увек недовољно истражену везу између миграције и старења у Србији (Manojlović, 2002; Milosavljević, Antonijević, 2015; Lukić, 2015) доприносећи бољем разумевању ефеката миграционог искуства на образац активности и квалитет живота старих људи. Наши налази су открили и како одлука о месту становања утиче на вредност пензије код пензионера повратника у погледу разлика у трошковима живота у Србији и другим земљама. У поређењу са другим испитаницима, пензионери повратници истичу се начином живота и вишим приходима који им омогућавају бољи квалитет слободног времена и смештаја што потврђује да је новац битан, како су то нагласили Екерсова и Двајер (Ackers, Dwyer, 2002: 107). Пошто су повратак планирали (привремена миграциона стратегија), они су циљано штедели и позитивно су одабрани у смислу прихода (Rodriguez, Egea, 2006). Постоје индиције да пензионери повратници из иностранства могу да приуште другачији начин живота и смештај у односу на друге групе старих. Већина испитаника има капацитет да допринесе породицама и заједницама, док су финансије значајан фактор који омогућава бољи квалитет живота у старости. Према нашим испитаницима, у домовима за стара лица постоји култура отворености (Van Malderen et al., 2013). Дугорочно настањене избеглице из бивших република Југославије и пензионери повратници из иностранства уживају законом загарантована права укључујући смештај у домовима за стара лица. Повратници, којима су, како се чини, одреднице активног старења које су у вези са друштвеном средином веома важне (WHO, 2002), посебно цене ову прилику, а постоје налази да се у другим земљама старији повратници суочавају с потешкоћама у проналажењу места у домовима за старе (Hardill et al., 2005). 


\section{Закључак}

Свако обликовање будуће популационе политике у Србији мора да узме у обзир чињеницу да демографско старење сада и у перспективи представља један од најзначајнијих изазова. Парадигма активног старења је најпривлачнија из стратешких разлога, будући да наглашава важност тога да старе особе треба да воде здрав и продуктиван живот и да се више укључе у заједницу. Активно старење, дакле, даје важан простор за маневрисање, потврђујући потребу за сталним истраживањем различитих могућности и различитих резерви које имају стари људи. Ипак, имајући у виду да су стари у Србији веома хетерогена група, проучавање активног старења мора да узме у обзир бројне факторе као што су миграциона историја, географска расподела, стамбене преференције, економске прилике итд. Импликације у погледу политике према старима у Србији, настале из нашег истраживања, показују да се активно старење у домовима за старе у Србији може остварити помоћу више бесплатних програма и уз помоћ пензионера повратника као важних чинилаца промена.

Будућа истраживања у (државним и приватним) домовима за стара лица могу додатно да истакну детерминанте активног старења које могу позитивно да утичу на ублажавање неповољних демографских трендова. Такође, при дефинисању ефикасних мера у циљу побољшања квалитета живота старијих грађана у Србији, потребни су даљи напори креатора политика и професионалаца који пружају услуге старијим особама. Дефинисање ефикасних мера у циљу побољшања квалитета живота старијих грађана и примена концепта активног старења у домовима за стара лица значи поштовање разлика међу хетерогеним групама старих људи.

\section{REFERENCES / ЛИTЕРATУРA}

Ackers, L, Dwyer, P. (2002). Senior citizenship? Retirement, migration and welfare in the European Union. Bristol: Policy Press.

Barriball, K, White, A. (1994). Collecting Data Using a Semi-Structured Interview: A Discussion Paper. Journal of Advanced Nursing, 19, 328-335.

Bernard, S. (2012). Developing the Yugoslav Gastarbeiter Reintegration Policy: Political and Economic Aspects (1969-1974). Working paper No. 5. Center for Southeast European Studies: Graz. Available at http://www.suedosteuropa.uni-graz.at/sites, default/files/publications/0.\%20WP5\%20Bernard.pdf

Bolzman, C, Kaeser, L. (2012). Active ageing and immigrant elders: A possible relation? Exploring the case of Switzerland. Revista Migracoes, 10, 29-44.

Botev, N. (2012). Population ageing in Central and Eastern Europe and its demographic and social context. European Journal of Ageing, 9(1), 69-79. DOI: 10.1007/s10433012-0217-9.

Cook, J. (2010). Exploring older women's citizenship: Understanding the impact of migration in later life. Ageing and Society, 30(2), 253-273.

Fernandez-Mayoralas, G, Rojo-Perez, F, Martınez-Martın, P. et al. (2015). Active ageing and quality of life: factors associated with participation in leisure activities among institutionalized older adults, with and without dementia. Aging \& Mental Health, 19 (11), 1031-1041. 
Весна М. Лукић, Јелена Н. Стојилковић Гњатовић, Сйареюе у Србији: йериейције..

Fusch P, Ness, L. (2015). Are we there yet? Data saturation in qualitative research. The Qualitative Report, 20(9), 1208-1416. Available at https://nsuworks.nova.edu/tqr vol20/iss9/3/

Hardill, I, Spradbery, J, Arnold-Boakes, J, Marrugat, M. L. (2005). Severe health and social care issues among British migrants who retire to Spain. Ageing and Society, 25(5), $769-783$.

Hoff, A. (2011). Introduction: The drivers of population ageing in Central and Eastern Europe - Fertility, Mortality and Migration. In: A. Hoff, (ed.) Population Ageing in Central and Eastern Europe: Societal and Policy Implications 1-11. Farnham: Ashgate Publishing.

Horgas, A, Wilms, H, Baltes, M. (1998). Daily Life in Very Old Age: Everyday Activities as Expression of Successful Living. The Gerontologist, 38(5), 556-568.

Krstić, M, Ljubičić, M. (2015). Migration of Health Care Workers from the Western BalkansAnalyzing Causes, Consequences and Policies: Country report Serbia. Skopje: Health Grouper.

Kupiszewski, M, Kupiszewska, D, Nikitovic, V. (2012). The impact of demographic and migration flows on Serbia. Belgrade: International Organization for Migration.

Van't Leven, N, Jonsson, H. (2002). Doing and being in the atmosphere of the doing: Environmental influences on occupational performance in a nursing home. Scandinavian Journal of Occupational Therapy, 9, 148-155.

Lukić, V. (2015). Socio-demographic characteristics of the elderly forced migrants in Serbia. Stanovništvo, 53(1), 39-61. DOI: https://doi.org/10.2298/STNV1501039I [In Serbian]

Manojlović, P. (2002). Return of the third age people from Diaspora in the function of improving the quality of life of people in the country of origin. Gerontologija, 1, 5154. [In Serbian]

Milosavljević, Lj, Antonijević, D. (2015). Nursing homes as the perspective and reality of guest workers in old age. Etnoantropološki problemi, 10(2), 333-355. [In Serbian]

Palloni, A, Pinto, G, Wong, R. (2009). Family Support Networks and Population Ageing. 13-16. In Paper presented at the seminar on family Support Networks and Population Aging, Doha International Institute for Family Studies and Development, UNFPA and Institute for Policy Research, Northwestern University, 3-4 June, Doha, Qatar. Available at https://www.unfpa.org/sites/default/files/pub-pdf/family_support_net works2009.pdf

Institute of Social Protection. (2015). The work report on institutional accommodation of older users in 2014. Beograd: Zavod za socijalnu zaštitu. [In Serbian]

Rodriguez, V, Egea, C. (2006). Return and the Social Environment of Anadalusian Emigrants in Europe. Journal of Ethnic and Migration Studies, 32(8), 1377-1393.

Ruspini, P. (2009). Elderly migrants in Europe: an overview of trends, policies and practices. Report for the European Committee on Migration of the Council of Europe (CDMG). Available at http://www.cermes.info/upload/docs/Elderly_migrants_in_ Europe_paolo_ruspini_14_07_10.pdf

Sadarangani, T, Jun, J. (2015). Newly Arriwed Elderly Immigrants: A Concept Analysis of "Aging Out of Place". Journal of Transcultural Nursing, 26(2), 110-117. DOI: $10.1177 / 1043659614549074$ 
Stojilković, J. (2010). „Baby boom“generation at the retirement onset. Stanovništvo, 48(2), 75-91. DOI: http://www.doiserbia.nb.rs/Article.aspx?ID=0038-982X1002075S. [In Serbian]

Stojilković Gnjatović, J, Sekulić, Lj. (2017). Ageing of baby boom generation in Serbia past, present and future trends. In: V. Janeska, Lozanoska, A. (eds.) The population of the Balkans at the dawn of the 21st century, 275-294. Skopje: Institute of Economics Skopje, Ss. Cyril and Methodius University in Skopje.

Taylor-Powell, E, Renner, M. (2003). Analyzing qualitative data. University of WisconsinExtension Program Development \& Evaluation Madison, WI, USA. Available at https://deltastate.edu/docs/irp/Analyzing\%20Qualitative\%20Data.pdf

Tomanović, S., Stanojević, D., Jarić, I., Mojić, D., Dragišić Labaš, S., Ljubičić, M., Živadinović, I. (2012). Young people our present. Beograd: Čigoja štampa: [In Serbian]

Van Malderen, L, Mets, T, De Vriendt, P, Gorus, E. (2013). The Active Ageing concept translated to the residential long-term care. Quality of Life Research, 22, 929-937.

Van Malderen. L. De Vriendt, P. Mets, T, Gorus, E. (2016). Active ageing within the nursing home: a study in Flanders, Belgium. European Journal of Ageing, 13, 219-230.

Vasara, P. (2015). Not ageing in place: Negotiating meanings of residency in age-related housing. Journal of Aging Studies, 35, 55-64.

Wahl, H. W., Deeg, D, Litwin, H. (2013). European ageing research in the social, behavioural and health areas: a multidimensional account. European Journal of Ageing, 10, 261-270.

Walker, A. (2002). A strategy for active ageing. International Social Security Review, 55, 121-139.

Walker, A. (2005). Quality of life in old age in Europe. In: A. Walker, (ed.) Growing Older in Europe, 1-31. Berkshire: Open University Press.

Walker, A. (2015). The concept of active ageing. In A. Walker, C. Aspalter, (eds.) Active Ageing in Asia, 14-29. New York: Routledge.

Walters, W. (2000). Types and patterns of Later-Life Migration. Geografiska Analer Series B Human Geography, 82(3), 129-147.

World Health Organisation (WHO). (2002). Active Ageing: a Policy Framework. World Health Organisation: Geneva. Available at http://www.who.int/ageing/publications/ active_ageing/en/

Zaidi, A, Gasior, K, Hofmarcher, M, Lelkes, O, Marin, B, Rodrigues, R, et al. (2013). Active Ageing Index 2012. Vienna: European Centre Vienna. 
Весна М. Лукић, Јелена Н. Стојилковић Гњатовић, Сйареюе у Србији: йериейције...

\section{APPENDIX / ПРИЛОЗИ}

Табела 1: Социо-демографске карактеристике испитаника/

Table 1: Socio-demographic characteristics of participants

\begin{tabular}{|c|c|c|c|c|c|c|}
\hline \multirow{2}{*}{$\begin{array}{c}\text { Године/ } \\
\text { Age }\end{array}$} & & $65-69$ & $70-74$ & $75-79$ & $80+$ & Укупно/Total \\
\hline & $\begin{array}{l}\text { Бpoj/ } \\
\text { Count }\end{array}$ & 5 & 3 & 7 & 12 & 27 \\
\hline \multirow{2}{*}{$\begin{array}{l}\text { Пол/ } \\
\text { Sex }\end{array}$} & $\begin{array}{c}\text { Мушки/ } \\
\text { Male }\end{array}$ & 2 & 1 & 1 & 6 & 10 \\
\hline & $\begin{array}{l}\text { Женски/ } \\
\text { Female }\end{array}$ & 3 & 2 & 6 & 6 & 17 \\
\hline \multirow{4}{*}{$\begin{array}{c}\text { Брачни статус/ } \\
\text { Marital status }\end{array}$} & $\begin{array}{l}\text { У браку/ } \\
\text { Married }\end{array}$ & 1 & & 1 & & 2 \\
\hline & $\begin{array}{c}\text { Никада није } \\
\text { био/ла у } \\
\text { браку/ } \\
\text { Never } \\
\text { married } \\
\end{array}$ & & 1 & 1 & & 2 \\
\hline & $\begin{array}{c}\text { Разведен/a/ } \\
\text { Divorced }\end{array}$ & 2 & 1 & & 2 & 5 \\
\hline & $\begin{array}{c}\text { Удовац, } \\
\text { удовица/ } \\
\text { Widowed } \\
\end{array}$ & 2 & 1 & 5 & 10 & 18 \\
\hline \multirow{4}{*}{$\begin{array}{c}\text { Образовање/ } \\
\text { Education at- } \\
\text { tainment }\end{array}$} & $\begin{array}{c}\text { Непотпуно } \\
\text { основно/ } \\
\text { Incomplete } \\
\text { primary }\end{array}$ & & & & 2 & 2 \\
\hline & $\begin{array}{c}\text { Основно/ } \\
\text { Primary }\end{array}$ & 1 & & 1 & 1 & 3 \\
\hline & $\begin{array}{l}\text { Средње/ } \\
\text { Secondary }\end{array}$ & 3 & 1 & 4 & 3 & 11 \\
\hline & $\begin{array}{c}\text { Терцијарно/ } \\
\text { Tertiary }\end{array}$ & 1 & 5 & 3 & 2 & 11 \\
\hline
\end{tabular}

